\title{
MASS DISTRIBUTION OF EARTH LANDFORMS DETERMINED BY ASPECTS OF THE GEOPOTENTIAL AS COMPUTED FROM THE GLOBAL GRAVITY FIELD MODEL EGM 2008
}

\author{
JAN KALVODA ${ }^{1}$, JAROSLAV KLOKOČNÍK², \\ JAN KOSTELECKY ${ }^{3}$, ALE Š BEZDĚK ${ }^{2}$ \\ ${ }^{1}$ Charles University in Prague, Faculty of Science, Department of Physical Geography and Geoecology \\ 2 Astronomical Institute, Academy of Sciences of the Czech Republic \\ ${ }^{3}$ Research Institute of Geodesy, Topography and Cartography
}

\section{ABSTRACT}

Correlations of large-scale landform patterns with some aspects of the geopotential as computed from the global gravity field model EGM 2008, particularly the radial second derivatives of the disturbing gravitational potential $\Gamma_{33}$, the strike angle $\theta_{S}$ and virtual deformations of the ellipse of deformation, are demonstrated. Selected regions with documentation of aspects from EGM 2008 are the Nepal Himalaya and its neighbouring areas, the collision zone of East-Asian and West-Pacific lithospheric plates, the contact region of north-eastern Africa, south-western Asia and south-eastern Europe, morphotectonic contact between the Bohemian Massif, Eastern Alps and the Western Carpathians in Central Europe and regions of ancient rapid events indicated by relics of large impact craters Vredefort, Chicxulub and Popigai. It is suggested that landform patterns with very conspicuous combinations of significantly high positive or negative values of $\Gamma_{33}$ are under the strong influence of rapid and/or intensive geomorphic processes. These geophysical signatures supported by values of the strike angle $\theta_{s}$ and virtual dilatations or compressions of the ellipse of deformation reflect the regional dynamics of Earth surface evolution as characterised by a very effective integration of tectonic and climate-driven morphogenetic processes.

Keywords: Earth landforms, gravity field model EGM 2008, mass distribution, geodynamics, geomorphic processes

\section{Introduction}

Progress in satellite geodesy and dynamics of the Earth's artificial satellites, involves satellite altimetry and space-born gradiometry data, together with an extensive, nearly global and often very precise database of terrestrial gravity anomalies. It enables the parameters of the static gravity field of the Earth (the so called harmonic geopotential coefficients or Stokes parameters represented by spherical expansion) to be reliably determined to a high degree and order, and detailed geoid undulations and other quantities derivable from the harmonic coefficients to be observed with high accuracy and resolution. The National Geospatial-Intelligence Agency of the USA developed the Earth Gravity Field Model 2008 (EGM 2008, Pavlis et al. 2008a,b, 2012) combined from the GRACE satellite data and gravity anomalies over the world (excluding Antarctica) to degree $n_{\max }=2190$.

Global combined gravity field models of the Earth, based on satellite and terrestrial data, can today have worldwide high resolution and precision. The EGM 2008 (Pavlis et al. 2008a,b, 2012) uses satellite multiyear inter-satellite range-rate data from a near polar orbiting tandem of satellites called GRACE (Gravity Recovery and Climate Experiment, NASA + GFZ) with extensive gravity anomalies derived from terrestrial gravimeters and satellite altimetry. EGM 2008 reaches a resolution of $5 \times 5 \mathrm{arcmin}$, which is $\sim 9 \mathrm{~km}$ of half-wavelength on the Earth's surface at the equator, and, with the exception of Antarctica and some other areas, a precision of the order 1 miliGal. Such a model offers new opportunities to many applications in geodesy, geophysics, geology, geomorphology and physical geography. The new data coming from the gradiometer on board GOCE (Gravity Field and Steady-State Ocean Circulation Explorer, ESA's gravity mission, Floberghagen et al. 2011) improve the middle-wavelength part (from 120 to 250 degrees) of future gravity models where satellite terrestrial data are wanting. The newest gravity field models from 2010-2011 also comprise gradiometry data from the satellite GOCE mission instead of data from GRACE (e.g. EIGEN 6C, Förste et al. 2011). They have only at maximum about half the resolution in comparison with EGM 2008 (Klokočník et al. 2012). Progress in the quality of quantities derived from their harmonic geopotential coefficients has been noted only in Antarctica.

In the presented paper, using the harmonic geopotential coefficients of the EGM 2008, are computed: the detailed geoid undulations $N[\mathrm{~m}]$, the gravity anomalies $\Delta g\left[1 \mathrm{mGal}=10^{-5} \mathrm{~m} \mathrm{~s}^{-2}\right]$, the full Marussi tensor of the second derivatives of the disturbing potential (also known as Full Tensor Gradiometry [ $1 \mathrm{E}=1$ Eötvös $=10^{-9} \mathrm{~s}^{-2}$ ]), namely its radial component $\Gamma_{33}$ (sometimes denoted $T_{z z}$ or $T_{r r}$ ) in spherical harmonics, the invariants of the gravity field $I_{0}, I_{1}, I_{2}$, computable from the components of the Marussi tensor, their specific ratio $I$ and the strike angle $\theta_{S}$, utilizing the theory of Pedersen and Rasmussen (1990) and Beiki and Pedersen (2010). A virtual dilatation or contraction of the ellipse of deformation is added. Some of these quantities are functionals of the geopotential in a mathematical sense and some of them are not. Therefore, they are concisely designated in the paper as aspects of the geopotential. 
In our project selected large-scale landform patterns are surveyed using a set of parameters computed from EGM 2008. The first recently published experimental results consisted in computing two anomalous parameters of the gravitational field in EGM 2008 (e.g. Kalvoda et al. 2010; Klokočník et al. 2010a), namely the gravity anomaly $\Delta g$ and the second-order radial derivative $\Gamma_{33}$ of the disturbing gravitational potential. The latter is not available directly from scattered ground gravity surveys. The second order derivatives and the invariants provide evidence about details of near-surface (not deep) structures. The Marussi tensor was already used in local scales (a few kilometers) for petroleum, metal, diamond, ground water etc. explorations (e.g. Mataragio and Kieley 2009; Murphy and Dickinson 2009). The full Marussi tensor is a richer source of information than standard single gravity anomalies. This extra information can be applied by tensor imaging techniques to enhance a target anomaly definition, as tested for local features (minerals, oil and gas industry), e.g., by Dickinson et al. (2009). Theoretical and experimental studies mentioned above were our stimulation to examine larger regions - in other words, to advance from local gradiometric measurements to the global gravity field models. Previously the gravity anomalies or the second derivatives were derived from gravimeters or gradiometers on airplanes. Recently, Beiki and Pedersen (2010) tested an approach to the larger area (ca $500 \times 500 \mathrm{~km}$ ) of the Vredefort impact crater in South Africa. These authors also used local measurements (a gradiometer on board of an airplane) but not Stokes parameters.

We computed the aspects listed above, based on a global gravity field model. The resolution achieved by the EGM 2008 is applicable and valuable for regional $\left(10^{2}-10^{3} \mathrm{~km}\right)$ and large-scale surveys and geo-applications. The local scale $(\sim 1 \mathrm{~km})$ is below the resolution of the EGM 2008. Tests of the sensitivity of the aspects of the EGM 2008 to selected landform patterns were realized by Klokočník et al. (2008a,b, 2010a,b) using especially large impact craters and by Kalvoda et al. (2010) in Himalayan regions with very conspicuous relief features of active orogeny and intensive climate-morphogenetic processes. The aim of the paper is to present examples of computed aspects of the EGM 2008 with suggestions of various geomorphological and geodynamic interpretations.

\section{Theory, data and computations}

\subsection{Description of theory}

The disturbing static gravitational potential outside the Earth masses in spherical coordinates in spherical expansion reads

$$
V(r, \varphi, \lambda)=\frac{G M}{r} \sum_{==2}^{\infty} \sum_{m=0}^{1}\left(\frac{R}{r}\right)^{\prime}\left(C_{1, m}^{\prime} \cos m \lambda+S_{1, m} \sin m \lambda\right) P_{1, m}(\sin \varphi),
$$

where $G M$ is a product of the universal gravity unit and the mass of the Earth (known from satellite analyses as a geocentric gravitational constant), $r$ is the radial distance of an external point where $V$ is computed, the symbol $R$ is for the radius of the Earth (which can be approximated by the semi-major axis of a reference ellipsoid), $P_{l, m}(\sin \varphi)$ are Legendre associated functions, $l$ and $m$ are the degree and order of the harmonic expansion, $(\varphi, \lambda)$ are geocentric latitude and longitude, $C_{l, m}^{\prime}$ and $S_{l, m}$ are harmonic geopotential coefficients (Stokes parameters), fully normalized, $C_{l, m}^{\prime}=C_{l, m}-C_{l, m}^{e l}$, where $C_{l, m}^{e l}$ belongs to the reference ellipsoid.

Gravity gradient tensor $\Gamma$ (the Marussi tensor) is a tensor of the second derivatives of the disturbing potential $V$ and is computed by means of $C_{l m}^{\prime}, S^{\prime}$ om the particular gravity field model known to the maximum degree $l_{\max }$ (see below details about EGM 2008):

$$
\Gamma=\left[\begin{array}{lll}
\Gamma_{11} & \Gamma_{12} & \Gamma_{13} \\
\Gamma_{21} & \Gamma_{22} & \Gamma_{23} \\
\Gamma_{31} & \Gamma_{32} & \Gamma_{33}
\end{array}\right]=\left[\begin{array}{lll}
\frac{\partial^{2} V}{\partial x^{2}} & \frac{\partial^{2} V}{\partial x \partial y} & \frac{\partial^{2} V}{\partial x \partial z} \\
\frac{\partial^{2} V}{\partial y \partial x} & \frac{\partial^{2} V}{\partial y^{2}} & \frac{\partial^{2} V}{\partial y \partial z} \\
\frac{\partial^{2} V}{\partial z \partial x} & \frac{\partial^{2} V}{\partial z \partial y} & \frac{\partial^{2} V}{\partial z^{2}}
\end{array}\right]
$$

The outside of the source $\Gamma$ satisfies Laplace's equation, the trace of the tensor is zero, $\Gamma$ is symmetric, and contains just five independent components. These can be conveniently computed by means of the formulae in Hotine (1969). The horizontal components help identify the shape and geological setting of a target body. The quantity $\Gamma_{33}$ is best suited for target body detection; $\Gamma_{33}$ helps to define isopath/density relationships of a body mass with relation to its geological setting (e.g., Murphy and Dickinson 2009).

Under any coordinate transformation, $\Gamma$ preserves three invariants

$I_{0}=\operatorname{trace}(\Gamma)=\Gamma_{11}+\Gamma_{22}+\Gamma_{33}$,

$I_{1}=\Gamma_{11} \Gamma_{22}+\Gamma_{22} \Gamma_{33}+\Gamma_{33} \Gamma_{11}-\Gamma_{12}{ }^{2}-\Gamma_{23}^{2}-\Gamma_{13}^{2}$,

$I_{2}=\operatorname{det}(\Gamma)=\Gamma_{11}\left(\Gamma_{22} \Gamma_{33}-\Gamma_{23}^{2}\right)+\Gamma_{12}\left(\Gamma_{23} \Gamma_{13}-\Gamma_{12} \Gamma_{33}\right)+$ $+\Gamma_{13}\left(\Gamma_{12} \Gamma_{23}-\Gamma_{13} \Gamma_{22}\right)$.

Pedersen and Rasmussen (1990) defined the ratio I of the invariants $I_{1}$ and $I_{2}$ as

$0 \leq I=-\left(I_{2} / 2\right)^{2} /\left(I_{1} / 2\right)^{3} \leq 1$.

It lies between zero and unity for any potential field. If the causative body is strictly $2-\mathrm{D}$, then $I$ is equal to zero.

The strike angle $\theta_{\mathrm{S}}$ is determined through

$\tan 2 \theta_{\mathrm{S}}=2 \frac{\Gamma_{12}\left(\Gamma_{11}+\Gamma_{22}\right)+\Gamma_{13} \Gamma_{23}}{\Gamma_{11}^{2}+\Gamma_{22}^{2}+\Gamma_{13}^{2}-\Gamma_{23}^{2}}=2 \frac{-\Gamma_{12} \Gamma_{33}+\Gamma_{13} \Gamma_{23}}{\Gamma_{13}^{2}-\Gamma_{23}^{2}+\Gamma_{33}\left(\Gamma_{11}-\Gamma_{22}\right)}$

within a multiple of $\pi / 2$. The strike angle indicates how gradiometer measurements rotate within the main directions of the underground structures. Provided that $I$ is 
small, the strike angle may indicate a dominant 2-D structure. For more details see, e.g., Pedersen and Rasmussen (1990) or Beiki and Pedersen (2010).

To define the term virtual deformation, we will utilize an analogy with the tidal deformation. If there is tidal potential $T$, then horizontal shifts (deformations) exist due to it and they can be expressed as follows in NorthSouth direction (latitude direction)

$u_{\mathrm{p}}=\mathrm{I}_{\mathrm{S}} \frac{1}{\mathrm{~g}} \frac{\partial \mathrm{T}}{\mathrm{g} \partial \varphi}$,

in East-West direction (longitudinal direction)

$u_{\Lambda}=I_{S} \frac{1}{g \cos \varphi} \frac{\partial T}{\partial \lambda}$,

where $g$ is gravity acceleration $9.81 \mathrm{~m} \mathrm{~s}^{-2}, l_{S}$ is the elastic coefficient (Shida number) expressing the elastic properties of the Earth as a whole planet $\left(l_{S}=0.08\right), \varphi$ and $\lambda$ are the geocentric coordinates of a point $P$ where we measure $T$. The potential $T$ is in $\left[\mathrm{m}^{2} \mathrm{~s}^{-2}\right]$ and in our case, $T$ is represented by (1), (8) and (9). This mechanism is applied to a standard Earth model (here EGM 2008), but real values of the Shida parameters $l$ for the Earth's surface are not known.

We apply the apparatus of mechanics of continuum to derive the main directions of the tension (e.g. Brdička et al. 2000). The tensor of deformation $\boldsymbol{E}$ is defined as a gradient of shift. Let us select a local coordinate system $(x, y)$ in $P$ by the equations

$$
\begin{gathered}
\mathrm{d} \varphi=\mathrm{d} x, \\
\mathrm{~d} \lambda \cos \varphi=\mathrm{d} y .
\end{gathered}
$$

Then it holds that

$$
\begin{gathered}
\mathrm{E}=\left(\begin{array}{ll}
\varepsilon_{11} & \varepsilon_{12} \\
\varepsilon_{21} & \varepsilon_{22}
\end{array}\right)= \\
\boldsymbol{d}=\boldsymbol{E} \boldsymbol{x}+\boldsymbol{t},
\end{gathered}
$$

where $\boldsymbol{d}$ is the vector of shift, $\boldsymbol{E}$ the gradient of shift, $\boldsymbol{x}$ the vector of the coordinates and $\boldsymbol{t}$ the vector of translation.

The tensor of deformation can be separated into two parts:

$\boldsymbol{E}=\boldsymbol{e}+\boldsymbol{\Omega}=\left(e_{\mathrm{ij}}\right)+\left(\Omega_{\mathrm{ij}}\right)$,

where $e$ is the symmetrical tensor and $\boldsymbol{\Omega}$ the anti-symmetrical tensor of deformation, respectively. We will need $\boldsymbol{e}$ :

$\mathrm{e}=\left(\begin{array}{ll}\mathrm{e}_{11} & \mathrm{e}_{12} \\ \mathrm{e}_{21} & \mathrm{e}_{22}\end{array}\right)=\left(\begin{array}{cc}\varepsilon_{11} & \frac{\left(\varepsilon_{12}+\varepsilon_{21}\right)}{2} \\ \frac{\left(\varepsilon_{12}+\varepsilon_{21}\right)}{2} & \varepsilon_{22}\end{array}\right)$

and the parameters of deformation

$\Delta=e_{11}+e_{22}$ (total dilatation), $\gamma_{1}=e_{11}-e_{22}$ (pure cut), $\gamma_{2}=2 e_{12}$ (technical cut),

$\gamma=\left(\gamma_{1}^{2}+\gamma_{2}^{2}\right)^{1 / 2}$ (total cut), $a=1 / 2(\Delta+\gamma)$ (major semi-axis of ellipse of deformation),

$b=1 / 2(\Delta-\gamma)$ (minor semi-axis of ellipse of deformation), $\alpha=1 / 2 \operatorname{atan}\left(\gamma_{2} / \gamma_{1}\right)$ (direction of main axis of deformation).
In relevant sketch maps of presented complex figures, the semi-axis of deformation ellipse $a$ and $b$ are expressed together with their relative size. Values of $l_{\mathrm{S}}$ are not known, and, therefore, only main directions of the virtual deformations (and not also their amplitudes) are demonstrated. The plotted quantities are $a$ and $b$ expressed in the figures as small crosses.

Virtual deformations of the ellipse of deformations, calculated using the tensor of deformation $\boldsymbol{E}$ (Eqn. 8-11), are geometrically expressed by its dilatation or compression. Virtual dilatations of the ellipse of deformation indicates uplifted regions at the geoid, whose mass has (according to the pattern of values of the gravitational potential) a tendency to disintegration. On the contrary, virtual compression of the ellipse of deformation indicates lowered zones and/or areas at the geoid. Natural processes which are the cause of these states of the near-surface part of the geoid, are certainly very diverse as a consequence of regionally heterogenous integration of morphotectonic and erosion-denudational processes. The suggested interpretation of the field of virtual deformations of the ellipse of deformation is also in agreement with regional patterns of the values of $\Delta g, \Gamma_{33}$ and $\theta_{S}$.

\subsection{Quality of data and computations}

The EGM 2008 (Pavlis et al. 2008a,b, 2012) is a combined solution (from satellite and terrestrial data) complete to the degree and order 2160 in a spherical harmonic expansion. It also contains additional coefficients extending to the degree 2190 and order 2159. Satellite data to the EGM 2008 come only from the GRACE A/B SST (low-low satellite-to-satellite tracking). The terrestrial data base of EGM 2008 is very extensive and consists of several sources (gravimetric measurements, anomalies derived from altimetry, models or fill-in data from digital models of the terrain) when nothing better was available. EGM 2008 is probably the best currently available combination gravity field model of the Earth. Nevertheless, it does not yield a homogeneous gravity anomaly field. For example, no terrestrial data in EGM 2008 are available for Antarctica. Only poorer data (the "fill-in" set from satellite topography, of lower precision, resolution and reliability) over high mountain belts are available (Pavlis et al. 2012). Although the data in EGM 2008 are in general of high quality, there are still large variations of the precision of the geoid undulation, gravity anomalies, and other quantities derived from $C_{l m}, S_{l m}$ of EGM 2008. Pavlis et al. (2008a) documented the accuracy estimates (see also Figures 1 and 2 in Kalvoda et al. 2010) for the gravity anomalies in EGM 2008, their variability over latitude and longitude from covariance analysis. The accuracy and resolution of the derivatives of the EGM 2008 geopotential for some of the mountain belts and other regions with the fill-in data can be several times lower than for the best covered areas. 
Plotting is important for visualizing our results; we make use of strongly non-linear scales to emphasize various features which otherwise might remain hidden. A note about the units of plotted functionals: $m G$ al for the gravity anomalies and/or disturbances, $E=$ Eötvös for the second order potential derivatives. The invariants $I_{1}$ and $I_{2}$ have units $\left[\mathrm{s}^{-4}\right]$ and $\left[\mathrm{s}^{-6}\right]$ and the ratio $I$ is spaceless. The strike angle $\theta_{S}$ is expressed in degrees and its demonstration in red means its direction to the East and in blue to the West of the meridian.

\section{Selected results of screening: aspects of the EGM 2008 in varied regions of the Earth}

A systematic screening was performed of correlations between aspects of the geopotential, as represented by the EGM 2008, and large-scale landform patterns displaying varied near-surface geological structures as well as climate-morphogenetic processes. Results of the screening are represented by means of examples from regions of various planation surfaces, high mountain ranges, collision zones of oceanic and continental lithospheric plates, volcanic chains and large impact craters. Selected regions with demonstration of aspects from EGM 2008 are as follows: the Nepal Himalaya and its neighbouring regions, the collision zone of East-Asian and West-Pacific lithospheric plates, the contact region of north-eastern Africa, south-western Asia and south-eastern Europe, morphotectonic contact between the Bohemian Massif, Eastern Alps and the Western Carpathians in Central Europe and regions of ancient rapid events indicated by relics of large impact craters Vredefort, Chicxulub and Popigai.

By means of the evaluation of an extensive set of graphical representations of values of selected aspects of the geopotential (computed from the EGM 2008), it was found that the most effective information for geo-applications is provided by 1 ) the radial second derivative of the disturbing gravitational $\Gamma_{33}, 2$ ) the strike angle $\theta_{S}$, and 3) virtual deformations of the ellipse of deformation (Klokočník et al. 2013). Variable values of $\Gamma_{33}$ display significant gravitational signatures of extensive differences and changes in mass density and/or rock massif and regolith distributions. Local directions of strike angle $\theta_{S}$ and virtual deformations of the ellipse of deformation form clusters, stripes and also zones with frequent space changes. These configurations can reflect and/or be closely related to directions of tectonic pressures in rock massifs of the Earth's landforms.

\section{The Nepal Himalaya and its neighbouring regions}

Strong coincidences were identified between the large-scale landform configuration of the Himalaya and the extension of regions with very high positive values of the radial second derivative of the disturbing gravitational potential $\Gamma_{33}$ and the most likely in combination with conspicuous areas of high negative values of $\Gamma_{33}$ in their close neighbourhood (Kalvoda et al. 2010). Specific configuration and sharp differences in orographical patterns of the Himalaya are indicated by a large range of values of $\Gamma_{33}$ approximately between $+1100 \mathrm{E}$ and $-760 \mathrm{E}$. It is a conspicuous reflection of high mountain massifs (Figure I in Colour appendix) divided by large canyon-like valleys of antecedent origin with very active deep-side erosion and related morphogenetic processes. High-mountain landforms and rapid exhumation of deep crystalline rocks in the Himalayan region of the collision orogeny are the result of morphotectonic processes, as well as denudation and erosional efficiency under variable palaeoclimatic conditions which occurred during the late Cenozoic (compare e.g. Kalvoda 1992, 2007).

A comparison of $\Delta g$ and $\Gamma_{33}$ records displaying the southern Himalayan foredeep, the Gangetic Plain is also very instructive. Negative gravity anomalies $\Delta g$ (Figure Ia) are sensitive to geological structure driven by a long-term subduction of the Indian sub-continent under the Asian continental plate. On the contrary, the second order derivatives $\Gamma$ (Figures Ib, c, d) reflect the near-surface mass distribution and flat accumulation landforms of the Gangetic Plain and dissected relief of the Siwalik Hills. Mountain ranges of the Himalaya are also demonstrated by the invariants (Figures Ie, f, g), namely by zones of the significantly negative $\boldsymbol{I}_{1}$ (Figure Ie) and positive $\boldsymbol{I}_{2}$ (Figure If). The eastern directions of the strike angle $\theta_{S}$ (Figure Ih, i) are very noticeable in the Gangetic Plain and the Siwalik Hills and its prevailingly western directions in the Himalayan and Tibetan regions. The main patterns of virtual deformations (Figure Ij), which are presented by dilatations and contractions of the ellipse of deformation, follow the extremely dissected relief of the Himalaya. Virtual dilatations of the ellipse of deformation are concentrated in mountain vaults, and, on the contrary, its virtual contractions indicate strikingly cut-down areas of the mountainous landscape.

\section{The collision zone of the East-Asian and West-Pacific lithospheric plates}

The main large-scale morphostructural patterns of the active collision zone between the Pacific (oceanic) and Asian (continental) plates are quite well expressed by the functionals $\Delta g$ (Figure IIa), $\Gamma_{33}$ (Figure IIb) and also partially by strike angle $\theta_{S}$ (Figure IIc). Mountain chains of Japanese islands, including the huge massifs of stratovolcanoes, can be determined in Figures IIa, b, especially by the stripes and clusters of positive values of $\Delta g$ and $\Gamma_{33}$. A striking feature drawn in Figures IIa, b, c, d is a remarkable arc of deep tectonic trenches connected with the active subduction of the Western-Pacific oceanic plate under the eastern margin of the Asian continental plate.

Virtual deformations derived from the ellipse of deformation (Figure IId) follow the positions of elevations and depressions of land and submarine reliefs. Demonstrated patterns of these virtual deformations are very similar to the occurrence of gravity anomalies 
$\Delta g$ (Figure IIa). The topographical features of the Kuril Islands, the Japanese Islands and groups of submarine volcanic massifs in the western part of the Pacific Ocean are especially noticeable, as expressed by positive values of $\Delta g$ and/or virtual dilatations (compare Figures IIa and IId). The Kuril and Japanese trenches are indicated by negative values of $\Delta g$ and/or virtual contractions of the ellipse of deformation.

\section{Contact region of north-eastern Africa, south-western Asia and south-eastern Europe}

The complicated geological and landform patterns of the large contact region between these continents can be estimated especially from configurations of highly positive or negative values of $\Delta g$ (Figure IIIa), $\Gamma_{33}$ (Figure IIIb) and the strike angle $\theta_{S}$ (Figure IIIc). The main orographical patterns including the mountain ranges between the Balkans and the Iranian Highland as well as tectonic basins (e.g. in the Mediterranean Sea west of Cyprus and between Crete and the northern coast of Africa) are conspicuously expressed by $\Delta g$ (Figure IIIa) and by virtual dilatations and contractions of the ellipse of deformation (Figure IIId). Also remarkable are zones with significantly high positive values of $\Gamma_{33}$ (Figure IIIb) combined with high negative values in close neighbourhoods. It is especially well rendered in regions of the Caucasus and the Elborz mountains (compare also Chapter 4 with details in Figure XI) as well as the narrow tectonic suture with the Dead Sea.

\section{Conspicuous morphotectonic contact between the Bohemian Massif, the Eastern Alps and the Western Carpathians in Central Europe}

An example of a varied geological and landform patterns is presented especially in Figures IVa, b, displaying $\Delta g$ and $\Gamma_{33}$ for the Bohemian Massif and its surrounding areas. This part of central Europe includes an extensive region of the geological contact between the Hercynian structures of the Bohemian Massif and the Tertiary Alpine and the Carpathian orogens to the south and/or east of them (compare e.g. Golonka et al. 2006). A combination of the gravity signatures $\Delta g$ and $\Gamma_{33}$ mediates an effective expression of the deeper and near-surface parts of the Earth's crust and landform patterns. There is a possibility that clusters of western and/or eastern directions of the strike angle $\theta_{S}$ (Figure IVc) could be a reflection of assumed pressures and tensions in rock massifs of these large morphotectonic units. Figure IVd shows the virtual deformations of the ellipse of deformation with pronounced patterns of mountain belts and highlands (virtual dilatations) and the mainly tectonically conditioned network of valleys and basins (virtual compressions) with active erosion and/or accumulation processes.

\section{Regions of the Vredefort, Chicxulub and Popigai impact craters}

The gravity signal of various impact craters on the Earth has been studied by, among others, Klokočník et al. (2010a,b). These authors suggested that some of the studied craters can not be single but double or multiple craters (Chicxulub and Popigai).

Vredefort, located in South Africa, is the largest confirmed impact crater on the Earth. Due to its large age $\left(2 \times 10^{9}\right.$ years $)$, the area underwent substantial structural-geological and erosion changes. Therefore, the impact crater is "fragmented" (Figures VIa, b, d). This indefinite state is especially manifested by the strike angle $\theta_{S}$ (Figure Vc).

Chicxulub is a large multi-ring impact crater in the north Yucatan at $\varphi=21^{\circ} 20^{\prime} \mathrm{N}$ and $\lambda=270^{\circ} 30^{\prime} \mathrm{E}$. Hildebrand et al. $(1995,1998)$ estimated its diameter as $170 \mathrm{~km}$ based on measured gravity profiles and by the location of rings of cenotes. Sharpton et al. (1993) identified two more distant rings in their gravity profiles and also interpreted a $300 \mathrm{~km}$-diameter crater. It is a relatively young impact structure (age $\sim 60 \times 10^{6}$ years) but completely buried under the surface and covered by Tertiary limestone. The Chicxulub impact crater was discovered by gravity anomalies measured during oil prospecting (for details and references see Klokočník 2008; Klokočník et al. 2010a,b). The geographical position and main structural patterns of the Chicxulub crater are well expressed using the gravity signatures $\Delta g$ (Figure VIa), $\Gamma_{33}$ (Figure VIb) and virtual deformations (Figures VIc, d). Virtual dilatations and compressions of the ellipse of deformation very closely follow the variable morphostructural, erosion and accumulation landform patterns of the Mexican and Caribean areas (Figures VIc, d), including details of the round structures of the Chicxulub impact crater. Figures VIc, d show the virtual deformations of the ellipse of deformation in Mexico and the Caribean (Campech bank) and in a detail the round structure of the compressed zone around the Chicxulub crater, coinciding with the negative anomalies and radial second derivatives. Two circular-like features of the Chicxulub crater are clearly visible (FigureVIb) with strong negative values of $\Gamma_{33}$ as well as a central part and two rings with positive values of $\Gamma_{33}$. The outer ring has a diameter of $160-180 \mathrm{~km}$. A hypothetical second (smaller) Chicxulub crater can also be identified - with some uncertainty - as a relief depression manifested by local virtual compressions of the ellipse of deformation (Figure VId).

The Popigai impact crater $\left(\varphi=71^{\circ} 39^{\prime} \mathrm{N}, \lambda=111^{\circ} 11^{\prime} \mathrm{E}\right)$ in Siberia, with a diameter of about $100 \mathrm{~km}$ and age $\sim 35 \times 10^{6}$ years (Pilkington et al. 2002; Masaitis et al. 2005), is partly visible on the surface. According to Klokočník et al. (2010a,b), the Popigai crater is probably not single (compare the gravity anomalies $\Delta g$ and second radial derivative $\Gamma_{33}$ in Figures VIIa, b), but double and may be a multiple crater. In Figures VIIc, $d$, the strike angle $\theta_{S}$ and the virtual deformations of the ellipse of deformation in the Popigai area are displayed, with striking circular structure of the impact crater (virtual compression) surrounded by irregular topographical elevations. 


\section{Discussion}

The presented examples of aspects of the EGM 2008 in geodynamically varied regions of the Earth enable the expression of some general findings and related remarks. The long-term activity of climate-morphogenetic processes in tectonically calm regions and in areas of active epeirogenesis resulted in the development of large planation surfaces and lowlands which are very close to geophysical levels of the same gravitational potential (Kalvoda et al. 2010). Therefore, it was found that on large-scale planation surfaces and topographically similar landforms, smoothed by denudation or accumulation of different genesis and age, values of the second derivatives of the disturbing gravitational potential $\Gamma_{33}$ are only in the range of approximately $\pm 100 \mathrm{E}$. On the contrary, regions of active orogeny and related morphotectonic processes are characterised by conspicuous compressions of rock massifs in the near-surface part of the Earth's crust and a very variable topographic mass distribution. These landform patterns are displayed by significantly high positive and/or negative values of $\Gamma_{33}$.

High negative values of $\Gamma_{33}$ have been indicated in regions of tectonically conditioned discontinuities or sinking of the Earth's surface and in regions with very intense erosion of rocks and transport of regolith. For example, the Lake Baikal rift zone is well observed as a strong and prolonged negative gravity anomaly $\Delta g$ and the radial second derivatives $\Gamma_{33}$ (Figures VIIIa, b). This significant orogenetic region also involves dissected mountainous relief evolving by intensive morphogenetic processes. Moreover, there are interesting landform patterns NW of Lake Baikal indicating an intersection of several tectonic faults.

The range of geomorphologic applications of EGM 2008 clearly depends on the quality of the regional gravity data as well as variability of the Earth surface processes. For example, landform patterns of the Grand Canyon in Arizona, originated by the intensive erosion processes of the Colorado River network along fault zones during long-term neotectonic uplifts of geological formations, are well expressed by EGM 2008 (Figures IXa, b). From various tests with volcanic mountains, the stratovolcanoes Popocatepetl and Iztaccihuatl are the most visible, as shown in Figures Xa, b. There are positive second derivatives $\Gamma_{33}$ located in the areas of the volcanoes, surrounded by "rings" around them with negative $\Gamma_{33}$.

Similar opinion can be expressed as an explanation of striking anomalies of the invariants. In regions with very noticeable features of active morphotectonic and erosion processes, very significant negative values $I_{1}$ and, on the contrary, positive values of $I_{2}$ were identified (compare Figures Ie, f, g). Similarly, it is possible to express and verify the hypothesis that directions of strike angle $\theta_{S}$ to a certain degree represent, or are in a harmony with, the prevailing directions of tectonic pressures and tensions in the near-surface part of the Earth's crust. Significant coincidences were also detected between regional patterns of $\Gamma_{33}$ and virtual deformations of the ellipse of deformation.

Landform patterns of the Earth provide regional evidence of the nature of very dynamic landscape evolution, including intense morphotectonic processes, variable rates of denudation, sediment transfer and deposition. Gravity data are therefore very valuable for establishing a better understanding of the processes driving uplift and erosion, especially in the regions with active orogenetic processes. Detected various large-scale configurations of selected functionals of the EGM 2008, which are particularly conspicuous on graphical representations of $\Gamma_{33}$ and $\theta_{S}$ values, give evidence of the long-term operation of certain complexes of morphogenetic processes producing the evolution of not only distinctive topographic features, but also, especially, of specific relief types of the Earth.

It is worth noting that striking coincidences between different aspects of the EGM 2008, representing regional geomorphic and structural-geological features of the Earth, are systematically identified. Examples of natural relations between selected aspects of the EGM 2008 suitable for variable geo-applications are demonstrated in Figure XI (the region of the southern part of the Caspian Sea) and Figure XII (the Ghawar oil fields in Saudi Arabia).

Selected aspects of the EGM 2008 in Figures XIa, b, c clearly indicate a continuation of an extensive morphotectonic depression (approximately of W-E direction, see also Figure III) originated between the southern Caucasus and the Iranian mountain belts. The Eastern part of the indicated graben-like zone forms a sedimentary basin of the southern part of the Caspian Sea situated at a foot of the very steep northern slopes of the Elborz mountains.

Similarly, a group of the aspects of the EGM 2008, expressed in the Ghawar region (Figure XII) in Saudi Arabia with one of the largest oil fields in the world (Al-Anazi 2007), can be well correlated with geomorphologic features and the structural-geological situation. Figures XIIa, b represent a detailed view of the values of the derivatives in a relatively small area of the Ghawar oil fields in Saudi Arabia $(\sim 100 \mathrm{~km}$ long in a south-north direction). Conspicuous harmony between a course of zones with positive values of $\Gamma_{33}$ (Figure XIIa) and virtual dilatations of the ellipse of deformation (Figure XIIb) testify in favour of the existence of matter elevation situated in a nearly longitudinal direction. This elevation is clearly surrounded on the western and eastern sides by zones of negative values of $\Gamma_{33}$ and/or virtual compressions of the ellipse of deformation, which can be interpreted as a manifestation of linear near-surface depressions.

Correlation of the displayed values of aspects of the geopotential as computed by means of the EGM 2008 on a sub-continental scale with their details in smaller regions (e.g. Figures XI and XII) as parts of a very large region (Figure III) confirms very good possibilities of an integrated approach to various geo-applications. Records 
of the present state of quantitative characteristics of the near-surface part of the geoid also make it possible to assess the recent dynamics of landform processes, notwithstanding the fact that calculations and their interpretations are based on the static gravity field model EGM 2008. For example, virtual dilatations of the ellipse of deformations give evidence of a tendency to gradual disintegration of topographical elevations. Moreover, significantly negative values of $\Gamma_{33}$ indicate zones of rapid erosion processes which are very often connected with active epeirogenetic or orogenetic uplifts. A possibility to use all groups of the functions of the geopotential, computed from EGM 2008, substantially increases the quality of their geodynamic interpretation. Although computed aspects are based on a one common gravity field model, represented in the paper by EGM 2008, they have very diverse morphogenetic features. All these findings can also be accepted as a recommendation for varied geo-applications.

\section{Conclusions}

An extensive screening of gravity signatures computed from EGM 2008 and their comparison with morphotectonic patterns and orographical features on a large scale was realized. From the methodological and interpretative points of view, it was confirmed that distributions of values of the second derivatives of the disturbing gravitational potential $\Gamma_{33}$ very precisely represent a near-surface (topographical) mass distribution. In this sense, a set of values of $\Gamma_{33}$ and their regional configurations are a consequence of landform evolution and reflections of both former and recent morphostructural and climate-morphogenetic processes (Kalvoda et al. 2010). Correlations of large-scale landform configurations with some aspects of the EGM 2008, particularly the radial second derivatives of the disturbing gravitational potential $\Gamma_{33}$, the strike angle $\theta_{S}$ and virtual deformation of the ellipse of deformation, are demonstrated in the selected regions of the Earth. These regions are characterized by large-scale planation surfaces, high mountain ranges, collision zones of oceanic and continental lithospheric plates, volcanic chains and impact craters.

It is suggested that landform patterns with very conspicuous combinations of significantly high positive or negative values of $\Gamma_{33}$ are under the strong influence of rapid and/or intensive geomorphic processes. Strong coincidences between a large-scale landform configuration of selected regions and the extension of areas with very high positive values of the radial second derivative of the disturbing gravitational potential $\Gamma_{33}$, and the most likely in combination with conspicuous areas of high negative values of $\Gamma_{33}$ in their close neighbourhood, have been identified. These geophysical signatures supported by values of the strike angle $\theta_{S}$ and virtual dilatations or compressions of the ellipse of deformation reflect the regional dynamics of Earth surface evolution as characterised by a very effective integration of tectonic and climate-driven morphogenetic processes.

Experimental studies of varied aspects of the geopotential as computed from the EGM 2008 are continuing. Topics are not only to determine the utmost limit of their interpretations but also to find new applications of the EGM 2008. Comparison of aspects of the geopotential computed by means of the EGM 2008 on a sub-continental scale with their details in smaller regions confirms advantages of an integrated approach to geo-applications.

\section{Acknowledgements}

The paper was completed in the framework of RVO 67985815 and with support provided by the European Space Agency grant C 908056 (PECS) and the projects P209/12/J068 and P209/13/36843S of the Grant Agency of the Czech Republic.

\section{REFERENCES}

AL-ANAZI, B. D. (2007): What you know about the Ghawar Oil Field, Saudi Arabia? CSEG Recorder, April, 40-43.

BEIKI, M., PEDERSEN, L. B. (2010): Eigenvector Analysis of Gravity Gradient Tensor to Locate Geologic Bodies, Geophysics, 75, 6, 137-149.

BRDIČKA, M., SAMEK, L., SOPKO, B. (2000): Mechanika kontinua (Continuum Mechanics), Academia, Praha.

DICKINSON, J. L., BREWSTER, J. R., ROBINSON, J. W., MURPHY, C. A. (2009): Imaging Techniques for Full Tensor Gravity Gradiometry Data, 11th SAGA Biennal Technological Meeting \& Exhibition, Swaziland, 16th-18th September, 84-88.

FLOBERGHAGEN, R., FEHRINGER, M., LAMARRE, D., MUZI, D., FROMMKNECHT, B., STEIGER, CH., PIÑEIRO, J., DA COSTA, A. (2011): Mission design, operation and exploitation of the gravity field and steady-state ocean circulation explorer mission. Journal of Geodesy, 85, 749-758.

FÖRSTE, CH., BRUINSMA, S., SHAKO, R., MARTY, J.-C., FLECHTNER, F., ABRIKOSOV, O., DAHLE, CH., LEMOINE, J. M., NEUMAYER, H., BIANCALE, R., BARTHELMES, F., KÖNIG, R., BALMINO, G. (2011): EIGEN-6A new combined global gravity field model including GOCE data from the collaboration of GFZ-Potsdam and GRGS-Toulouse, EGU General Assembly 2011, 3rd-8th April 2011, Vienna, Austria.

GOLONKA, J., PICHA, F. J. (eds.) (2006): The Carpathians and their foreland: geology and hydrocarbon resources. American Association of Petroleum Geologists, Edition: Memoir, 84, 600 pp., Tulsa.

HILDEBRAND, A. R., PILKINGTON, M., CONNORS, M., ORTIZ-ALEMAN, C., CHAVEZ, R. E. (1995): Size and structure of the Chicxulub crater revealed by horizontal gravity gradients and cenotes. Nature, 376, 415-417.

HILDEBRAND, A. R. and 10 others (1998): Mapping Chicxulub craters structure with gravity and seismic reflection data. In: Grady, M. M. (Ed.): Meteorites: Flux with Time and Impact Effects. Geological Society of London, Special Publications, 140, 155-176. 
HOTINE, M. (1969): Mathematical Geodesy, ESSA, US. Dept. Comm., Environ. Sci. Services Admin., Monograph 2, Washington, D.C.

HOLMES, S. A., PAVLIS, N. K., NOVÁK, P. (2006): A Fortran Program for Very-high Degree Harmonic Synthesis, version 05/01/2006

KALVODA, J. (1992): Geomorphological Record of the Quaternary Orogeny in the Himalaya and the Karakoram. In: Development in Earth Surface Processes 3, Elsevier, 315 pp., Amsterdam.

KALVODA, J. (2007): Dynamics of landform evolution in the Makalu - Barun region, Nepal Himalaya. Geografický časopis, 59, 2, 85-106, Bratislava.

KALVODA, J., KLOKOČNÍK, J, KOSTELECKÝ, J. (2010): Regional correlation of the Earth Gravitational Model 2008 with morphogenetic patterns of the Nepal Himalaya, Acta Universitatis Carolinae, Geographica, XLV, 2, 53-78, Prague.

KLOKOČNÍK, J. (ed.) (2008): Detection of Hidden Impact (Meteoritic) Structures: Introduction Study and Simulations Before the GOCE Launch, Report: Grant ESA/PECS C-98056 "GOCE - Specific Tasks on Fine Gravity Field Structure of the Earth", Report of Astronom. Inst. Czech Acad. Sci., Ondřejov Obs., $101 \mathrm{pp}$.

KLOKOČNÍK, J., KOSTELECKÝ, J., WAGNER, C. A. (2008a): Improvement in the radial accuracy of altimeter-satelite orbits to the geopotential. Earth-Science Reviews, 91, 1-4, 106-120.

KLOKOČNIIK, J., NOVÁK, P., PEŠEK, I., KOSTELECKÝ, J., WAGNER, C. A. (2008b): EGM 08: tests of the model and simulations for GOCE. IAG Symposium on Gravity, Geoid and Earth Observations, Chania, Crete, 23th-27th June, Greece.

KLOKOČNÍK, J., NOVÁK, P., KOSTELECKÝ, J., WAGNER, C. A. (2010a): Detection of Earth impact craters aided by the detailed global gravitational model EGM 2008. Acta Geodynamica et Geomaterialia, 7, 1 (157), 71-97, Prague.

KLOKOČNÍK, J., KOSTELECKÝ, J., PEŠEK, I., NOVÁK, P., WAGNER, C. A., SEBERA, J. (2010b): Candidates for Multiple Impact Craters? Popigai and Chicxulub as seen by the Global High Resolution Gravitational Field Model EGM08, Solid Earth EGU, 1, 71-83, doi: 10.5194/se-1-71-2010.

KLOKOČNÍK, J., KOSTELECKÝ, J., SEBERA, J., BEZDĚK, A. (2012): Comparison of EIGEN 6C and EGM 2008 Gravity Field Models via Marussi Tensor, computed for Selected Areas on the Earth, EGU General Assembly 2012, 22nd-27th April, Vienna, Austria.

KLOKOČNÍK, J., KOSTELECKÝ, J., KALVODA, J., SEBERA, J., BEZDĚK, A. (2012): Towards a System of Data Systems in Geoscience: Marussi Tensor and Invariants of the Earth Gravity Field from Recent Global Gravity Models EGM 2008 and EIGEN 6C based on Satellite (GRACE or GOCE) and Terrestrial Data. Poster, the Japan Geoscience Union Meeting 2012, 20th-25th May, Makuhari, Chiba, Japan.

KLOKOČNÍK, J., KALVODA, J., KOSTELECKÝ, J., BEZDĚK, A. (2013): Gravity Disturbances, the Marussi Tensor, Invariants and Other Functions of the Geopotential as Represented by the Global Gravity Field Model EGM 2008 and Suggestions for Geo-applications. Poster, ESA Living Planet Symposium, 9th-13th September, 2013, Edinburgh.

MASAITIS, V. L., NAUMOV, M. V., MASHCHAK, M. S. (2005): Original Diameter and Depth of Erosion of the Popigai Impact Crater, Russia. In: Kenkmann, T., Hörz, F., Deutsch, A. (Eds.), Large Meteorite Impacts III, The Geological Society of America, Special paper, 384, 131-140.

MATARAGIO, J., KIELEY, J. (2009): Application of Full Tensor Gradient Invariants in Detection of Intrusion-Hosted Sulphide Mineralization: Implications for Deposition
Mechanisms, Minig Geoscience, EAGE 1st break, vol. 27, 95-98.

MORITZ, H. (1984): Geodetic Reference System 1980. Bulletin Géodesique, 58, 388-398.

MURPHY, C. A., DICKINSON, J. L. (2009): Exploring Exploration Play Models with FTG Gravity Data, 11th SAGA Biennal Technological Meeting \& Exhibition, 16-18th September, Swaziland, 89-91.

PAVLIS, N. K., HOLMES, S. A., KENYON, S. C., FACTOR, J. K. (2008a): EGM2008: An Overview of Its Development and Evaluation, National Geospatial-Intelligence Agency, USA. The International Conference of Gravity, Geoid and Earth Observation 2008, 23th-27th June, Chania, Crete, Greece.

PAVLIS, N. K., HOLMES, S. A., KENYON, S. C., FACTOR, J. K. (2008b): An Earth Gravitational Model to Degree 2160: EGM2008, EGU General Assembly 2008, 13th-18th April, Vienna, Austria.

PAVLIS, N. K., HOLMES, S. A., KENYON, S.C., FACTOR, J. K. (2012): The Development and Evaluation of the Earth Gravitational Model 2008 (EGM2008), Journal of Geophysical Research, 117, B04406, doi: 10.1029/2011JB008916.

PEDERSEN, B. D., RASMUSSEN, T. M. (1990): The Gradient Tensor of Potential Field Anomalies: Some implications on data Collection and Data Processing of Maps. Geophysics, 55, \#12, $1558-1566$

PILKINGTON, M., PESONEN, L. J., GRIEVE, R. A. F., MASAITIS, V. L. (2002): Geophysics and Petrophysics of the Popigai Impact Structure, Siberia. In: Plado, J., Pesonene, L. J. (Eds.): Impacts in Precambrian Shields, Springer-Verlag, 87-107.

RABUS, B., EINEDER, M., ROTH, A., BAMLER, R. (2003): The Shuttle radar topography mission - a new class of digital elevation models acquired by spaceborne radar. Photogrammetry and Remote Sensing, 57, 241-262.

RUMMEL, R., COLOMBO, O. L. (1985): Gravity Field Determination from Satelite Gradiometry, Bulletin Géodesique, $59,233-246$.

SEBERA, J., WAGNER, C. A., BEZDĚK, A., KLOKOČNÍK, J. (2012): Guide to Direct Gravitational Field Modelling with Hotine's equations, Journal of Geodesy, on-line, 1-16, doi: 10.1007/s00190-012-0591-2.

SHARPTON, V. L. et al. (1993): Chicxulub multi-ring impact basin: Size and other characteristics derived from gravity analysis. Science, 261, 1564-1567.

\section{RÉSUMÉ}

\section{Rozložení hmoty povrchových tvarů Země zjištěné aspekty geopotenciálu vypočtenými z globálního modelu tíhového pole EGM 2008}

V práci jsou porovnány povrchové tvary Země s vybranými aspekty (deriváty) geopotenciálu vypočtenými z globálního modelu tíhového pole EGM 2008, a to zvláště s radiální složkou poruchového tíhového potenciálu $\Gamma_{33}$, úhlem posunu $\theta_{S}$ a virtuální dilatací či kompresí elipsy deformace. Byl proveden systematický skríning aspektů geopotenciálu určených z EGM 2008 a jejich korelace s rozsáhlými povrchovými tvary, které jsou důsledkem geologické stavby a klimato-morfogenetických procesů. Výsledky tohoto skríningu a korelací jsou ukázány na prŕkladech oblastí se zarovnanými povrchy, vysokých pohoří, kolizních zón, oceánských 
a pevninských litosférických desek, vulkanických masivů a velkých impaktních kráterů. Vybrané regionální př́klady korelace aspektů geopotenciálu vypočtených z EGM 2008 s uspořádáním povrchových tvarů Země jsou Nepálský Himálaj, kolizní zóna Východoasijské a Západopacifické litosférické desky, styčná zóna severovýchodní Afriky, jihozápadní Asie a jihovýchodní Evropy, morfotektonický kontakt mezi Českým masivem, Východními Alpami a Západními Karpatami ve střední Evropě a území s relikty velkých impaktních kráterů Vredefort, Chicxulub a Popigai. Dále je navržena a dokumentována interpretace, že rozsáhlé povrchové tvary s velmi nápadnou kombinací vysoce kladných a záporných hodnot poruchového tíhového potenciálu $\Gamma_{33}$ jsou silně ovlivněny intenzivními geomorfologickými procesy. Tyto geofyzikální charakteristiky, podpořené specifickými hodnotami úhlu posunu $\theta_{S}$ a virtuální dilatace či komprese elipsy deformace, jsou reflexí dynamiky vývoje zemského povrchu, která je podmíněna velmi efektivní integrací morfotektonických a klimato-morfogenetických procesů.

\title{
Jan Kalvoda
}

Charles University in Prague, Faculty of Science

Albertov 6, CZ-128 43, Prague 2, Czech Republic

E-mail:kalvoda@natur.cuni.cz

Jaroslav Klokočník

Astronomical Institute, Academy of Sciences of the Czech Republic

Fričova 298, CZ-251 65, Ondřejov, Czech Republic

E-mail:jklokocn@asu.cas.cz

Jan Kostelecký

Research Institute of Geodesy, Topography and Cartography

CZ-250 66, Zdiby 98, Czech Republic

E-mail:kost@fsv.cvut.cz

\author{
Aleš Bezděk \\ Astronomical Institute, Academy of Sciences of the Czech Republic \\ Fričova 298, CZ-251 65, Ondřejov, Czech Republic \\ E-mail:bezdek@asu.cas.cz
}

